\title{
CONFERÊNCIA
}

\section{Ecosocialism: towards a new civilization ${ }^{1}$}

Michael Löny - Diretor de pesquisas em ciências sociais do Centre National dês Recherches Scientifiques (CNRS), e professor da Université Paris XIII e da École des Hautes Études em Sciences, em Paris, França.

The present economical and ecological crisis are part of a more general historical conjoncture: we are confronted with a crisis of the present model of civilization, the Western modern capitalist/industrial civilization, based on unlimited expansion and accumulation of capital, on the "commodification of everything" (Immanuel Wallerstein), on the ruthless exploitation of labour and nature, on brutal individualism and competition, and on the massive destruction of the environment. The increasing threat of the breakdown of the ecological balance points towards a catastrophic scenario - global warming - that puts in danger the survival itself of the human species. We are facing a crisis of civilization that demands radical change. ${ }^{2}$

Ecosocialism is an attempt to provide a radical civilizational alternative, rooted on the basic arguments of the ecological movement, and of the Marxist critique of political economy. It opposes to the capitalist destructive progress (Marx) an economic policy founded on non-monetary and extra-economic criteria: the social needs and the ecological equilibrium. This dialectical synthesis, attempted by a broad spectrum of authors, from James O'Connor to Joel Kovel and John Bellamy Foster, and from André Gorz (in his early writings) to Elmar Altvater, is at the same time a critique of "market ecology", which does not challenge the capitalist system, and of "productivist socialism", which ignores the issue of natural limits.

According to James O'Connor, the aim of ecological socialism is a new society based on ecological rationality, democratic control, social equality, and

1 Texto de conferência proferido em janeiro de 2009, em Belém, no âmbito da programação do Fórum Social Mundial, a convite da Universidade Federal do Amazonas/UFAM e da Universidade Federal do Pará/UFPA, Núcleo de Altos Estudos Amazônicos (NAEA)

2 For a remarkable analysis of the destructive logic of capital, see Joel Kovel, The Enemy of Nature. The End of Capitalism or the End of the World?, N.York,; Zed Books, 2002. 
the predominance of use-value over exchange-value. I would add that this aims require: a) collective ownership of the means of production, - "collective" here meaning public, cooperative or comunitarian property; b) democratic planning that makes it possible for society to define the goals of investment and production, and c) a new technological structure of the productive forces. In other terms: a revolutionary social and economic transformation. ${ }^{3}$

The problem with the dominant trends of the left during the 20th century social-democracy and the Soviet-inspired communist movement - is their acceptance of the really existing pattern of productive forces. While the first limited themselves to a reformed - at best keynesian - version of the capitalist system, the second ones developed a collectivist - or state-capitalist - form of productivism. In both cases, environmental issues remained out of sight, or were marginalised.

Marx and Engels themselves were not unaware of the environmentaldestructive consequences of the capitalist mode of production: there are several passages in Capital and other writings that point to this understanding. ${ }^{4}$ Moreover, they believed that the aim of socialism is not to produce more and more commodities, but to give human beings free time to fully develop their potentialities. In so far, they have little in common with "productivism", i.e. with the idea that the unlimited expansion of production is an aim in itself.

However, there are some passages in their writings who seem to suggest that socialism will permit the development of productive forces beyond the limits imposed on them by the capitalist system. According to this approach, the socialist transformation concerns only the capitalist relations of production, which have become an obstacle - "chains" is the term often used - to the free development of the existing productive forces; socialism would mean above all the social appropriation of these productive capacities, putting them at the service of the workers. To quote a passage from Anti-Dübring, a canonical work for many generations of Marxists: in

3 John Bellamy Foster uses the concept of "ecological revolution", but he argues that "a global ecological revolution worthy of the name can only occur as part of a larger social - and I would insist, socialist - revolution. Such a revolution (...) would demand, as Marx insisted, that the associated producers rationally regulate the human metabolic relation with nature. (...) It must take its inspiration from William Morris, one of the most original and ecological followers of Karl Marx, from Gandhi, and from other radical, revolutionary and materialist figures, including Marx himself, stretching as far back as Epicurus". ("Organizing Ecological Revolution", Monthly Review, 57.5, October 2005, pp. 9-10).

See John Bellamy Foster, Marx's Ecology. Materialism and Nature, New York, Monthly Review Press, 2000 socialism "society takes possession openly and without detours of the productive forces that have become too large" for the existing system. ${ }^{5}$

The experience of the Soviet Union illustrates the problems that result from a collectivist appropriation of the capitalist productive apparatus: since the beginning, the thesis of the socialization of the existing productive forces predominated. It is true that during the first years after the October Revolution an ecological current was able to develop, and certain (limited) protectionist measures were taken by the Soviet authorities. However, with the process of Stalinist bureaucratization, the productivist tendencies, both in industry and agriculture, were imposed with totalitarian methods, while the ecologists were marginalised or eliminated. The catastrophe of Tchernobyl is an extreme exemple of the disastrous consequences of this imitation the Western productive technologies. A change in the forms of property which is not followed by democratic management and a reorganization of the productive system can only lead to a dead end.

Marxists could take their inspiration from Marx' remarks on the Paris Commune: workers cannot take possession of the capitalist state apparatus and put it to function at their service. They have to "break it" and replace it by a radically different, democratic and non-statist form of political power.

The same applies, mutatis mutandis, to the productive apparataus: by its nature, its structure, it is not neutral, but at the service of capital accumulation and the unlimited expansion of the market. It is in contradiction with the needs of environment-protection and with the health of the population. One must therefore "revolutionize" it, in a process of radical transformation. This may mean, for certain branches of production, to discontinue them: for instance, nuclear plants, certain methods of mass/industrial fishing (responsible for the extermination of several species in the seas), the destructive logging of tropical forests, etc (the list is very long !). In any case, the productive forces, and not only the relations of production, have to be deeply changed - to begin with, by a revolution in the energy-system, with the replacement of the present sources -essentially fossile - responsible for the pollution and poisoning of the environment, by renewable ones: water, wind, sun. Of course, many scientific and technological achievements of modernity are precious, but the whole productive system must be transformed, and this can be done only by ecosocialist methods, i.e. through a democratic planning of the economy which takes into account the preservation of the ecological equilibrium.

F. Engels, Anti-D iubring, Paris, Ed. Sociales, 1950, p. 318. 
The issue of energy is decisive for this process of civilizational change. Fossile energies (oil, coal) are responsible for much of the planet's pollution, as well as for the disastrous climate change; nuclear energy is a false alternative, not only because of the danger of new Tchernobyls, but also because nobody knows what to do with the thousands of tons of radioactive waist - toxic for hundreds, thousands and in some case millions of years - and the gigantic masses of contaminated obsolete plants. Solar energy, which did never arise much interest in capitalist societies, not being "profitable" nor "competitive", would become the object of intensive research and development, and play a key role in the building of an alternative energetic system.

Entire sectors of the productive system are to be suppressed, or restructured, new ones have to be developed, under the necessary condition of full employment for all the labour force, in equal conditions of work and wage. This condition is essential, not only because it is a requirement of social justice, but in order to assure the workers support for the process of structural transformation of the productive forces. This process is impossible without public control over the means of production, and planning, i.e. public decisions on investment and technological change, which must be taken away from the banks and capitalist enterprises in order to serve society's common good.

Society itself, and not a small olygarchy of property-owners - nor an elite of techno-bureaucrats - of will be able to choose, democratically, which productive lines are to be privileged, and how much resources are to be invested in education, health or culture. The prices of goods themselves would not be left to the "laws of offer and demand" but, to some extent, determined according to social and political options, as well as ecological criteria, leading to taxes on certain products, and subsidized prices for others. Ideally, as the transition to socialism moves forward, more and more products and services would be distributed free of charge, according to the will of the citizens. Far from being "despotic" in itself, planning is the exercise, by a whole society, of its freedom: freedom of decision, and liberation from the alienated and reified "economic laws" of the capitalist system, which determined the individuals" life and death, and enclosed them in an economic "iron cage" (Max Weber). Planning and the reduction of labor time are the two decisive steps of humanity towards what Marx called "the kingdom of freedom". A significant increase of free time is in fact a condition for the democratic participation of the working people in the democratic discussion and management of economy and of society.
The socialist conception of planning is nothing else as the radical democratization of economy: if political decisions are not to be left for a small elite of rulers, why should not the same principle apply to economic ones? I'm leaving aside the issue of the specific proportion between planning and market mechanisms: during the first stages of a new society, markets will certainly keep an important place, but as the transition to socialism advances, planning would become more and more predominant, as against the laws of exchange-value.

While in capitalism the use-value is only a means - often a trick - at the service of exchange-value and profit - which explains, by the way, why so many products in the present society are substantially useless - in a planned socialist economy the use-value is the only criteria for the production of goods and services, with far reaching economic, social and ecological consequences. As Joel Kovel observed: "The enhancement of use-values and the corresponding restructuring of needs becomes now the social regulator of technology rather than, as under capital, the conversion of time into surplus value and money". ${ }^{6}$

In a rationally organised production, the plan concerns the main economic options, not the administration of local restaurants, groceries and bakeries, small shops, artisan enterprises or services. It is important to emphasize that planning is not contradictory with workers self-management of their productive units: while the decision to transform an auto-plant into one producing buses and trams is taken by society as a whole, through the plan, the internal organization and functioning of the plant is to be democratically managed by its own workers. There has been much discussion on the "centralised" or "decentralised" character of planning, but it could be argued that the real issue is democratic control of the plan, on all its levels, local, regional, national, continental and, hopefully, international: ecological issues such as global warming are planetary and can be dealt with only on a global scale. One could call this proposition global democratic planning; it is quite the opposite of what is usually described as "central planning", since the economic and social decisions are not taken by any "center", but democratically decided by the concerned population.

Ecosocialist planning is therefore grounded on a democratic and pluralist debate, on all the levels where decisions are to be taken: different propositions are submitted to the concerned people, in the form of parties, platforms, or any other political movements, and delegates are accordingly elected. However, representative

6 Joel Kovel, Enemy of Nature, p. 215. 
democracy must be completed - and corrected - by direct democracy, where people directly choose - at the local, national and, later, global level - between major social and ecological options: should public transportation be free? Should the owners of private cars pay special taxes to subsidize public transportation? Should sun-produced energy be subsidized, in order to compete with fossile energy? Should the weekly work hours be reduced to 30, 25 or less, even if this means a reduction of production? The democratic nature of planning is not contradictory with the existence of experts, but their role is not to decide, but to present their views - often different, if not contradictory - to the population, and let it choose the best solution.

What guarantee is that the people will make the correct ecological choices, even at the price of giving up some of its habits of consumption? There is no such "guarantee", other than the wager on the rationality of democratic decisions, once the power of commodity fetichism is broken. Of course, errors will be committed by the popular choices, but who believes that the experts do not make errors themselves? One cannot imagine the establishment of such a new society without the majority of the population having achieved, by their struggles, their self-education, and their social experience, a high level of socialist/ecological consciousness, and this makes it reasonable to suppose that errors - including decisions which are inconsistent with environmental needs - will be corrected. In any case, are not the proposed alternatives - the blind market, or an ecological dictatorship of "experts" - much more dangerous than the democratic process, with all its contradictions?

The passage from capitalist "destructive progress" to ecosocialism is an historical process, a permanent revolutionary transformation of society, culture and mentalities. This transition would lead not only to a new mode of production and an egalitarian and democratic society, but also to an alternative mode of life, a new ecosocialist civilization, beyond the reign of money, beyond consumption habits artificially produced by advertising, and beyond the unlimited production of commodities that are useless and/or harmful to the environment. It is important to emphasize that such a process cannot begin without a revolutionary transformation of social and political structures, and the active support, by the vast majority of the population, of an ecosocialist program. The development of socialist consciousness and ecological awareness is a process, where the decisive factor is peoples own collective experience of struggle, from local and partial confrontations to the radical change of society.
Should development be pursued, or should one choose "negative growth" (décroissance)? It seems to me that these two options share a purely quantitative conception of - positive or negative - "growth", or of the development of productive forces. There is a third position, which seems to me more appropriate: a qualitative transformation of development. This means putting an end to the monstrous waste of resources by capitalism, based on the production, in a large scale, of useless and/or harmful products: the armaments industry is a good example, but a great part of the "goods" produced in capitalism - with their inbuilt obsolescence - have no other usefulness but to generate profit for the great corporations. The issue is not "excessive consumption" in abstract, but the prevalent type of consumption, based as it is on conspicuous appropriation, massive waste, mercantile alienation, obsessive accumulation of goods, and the compulsive acquisition of pseudo-novelties imposed by "fashion". A new society would orient production towards the satisfaction of authentic needs, beginning with those which could be described as "biblical" - water, food, clothing, housing - but including also the basic services: health, education, transport, culture.

Obviously, the countries of the South, were these needs are very far from being satisfied, will need a much higher level of "development" - building railroads, hospitals, sewage systems, and other infra-structures - than the advanced industrial ones. But there is no reason why this cannot be accomplished with a productive system that is environment-friendly and based on renewable energies. These countries will need to grow great amounts of food to nourish their hungry population, but this can be much better achieved - as the peasant movements organised world-wide in the Via Campesina network have been arguing for years by a peasant biological agriculture based of family-units, cooperatives or collectivist farms, rather than by the destructive and anti-social methods of industrialised agro-business, based on the intensive use of pesticides, chemicals and GMOs. Instead of the present monstruous debt-system, and the imperialist exploitations of the resources of the South by the industrial/capitalist countries, there would be a flow of technical and economic help from the North to the South, without the need - as some Puritan and ascetic ecologists seem to believe - for the population in Europe or North America to "reduce their standard of living": they will only get rid of the obsessive consumption, induced by the capitalist system, of useless commodities that do not correspond to any real need.

How to distinguish the authentic from the artificial, false and makeshift needs? The last ones are induced by mental manipulation, i.e. advertisement. The 
advertisement system has invaded all spheres of human life in modern capitalist societies: not only nourishment and clothing, but sports, culture, religion and politics are shaped according to its rules. It has invaded our streets, mail boxes, TV-screens, newspapers, landscapes, in a permanent, aggressive and insidious way, and it decisively contributes to habits of conspicuous and compulsive consumption. Moreover, it wastes an astronomic amount of oil, electricity, labor time, paper, chemicals, and other raw materials - all paid by the consumers - in a branch of "production" which is not only useless, from a human viewpoint, but directly in contradiction with real social needs. While advertisement is an indispensable dimension of the capitalist market economy, it would have no place in a society in transition to socialism, where it would be replaced by information on goods and services provided by consumer associations. The criteria for distinguishing an authentic from an artificial need, is its persistence after the suppression of advertisement (Coca Cola !). Of course, during some years, old habits of consumption would persist, and nobody has the right to tell the people what their needs are. The change in the patterns of consumption is a historical process, as well as an educational challenge.

Some commodities, such as the individual car, raise more complex problems. Private cars are a public nuisance, killing and maiming hundreds of thousand people yearly on world scale, polluting the air in the great towns - with dire consequences for the health of children and older people - and significantly contributing to the climate change. However, they correspond to a real need, by transporting people to their work, home or leisure. Local experiences in some European towns with ecologically minded administrations, show that it is possible - and approved by the majority of the population - to progressively limit the part of the individual automobile in circulation, to the advantage of buses and trams. In a process of transition to ecosocialism, where public transportation - above or underground - would be vastly extended and free of charge for the users, and where foot-walkers and bicycle-riders will have protected lanes, the private car would have a much smaller role as in bourgeois society, where it has become a fetish commodity - promoted by insistent and aggressive advertisement - a prestige symbol, an identity sign - in the US, the drivers license is the recognized ID - and the center of personal, social or erotical life.

Ecosocialism is based on a wager, which was already Marx's: the predominance, in a society without classes and liberated of capitalist alienation, of "being" over "having", i.e. of free time for the personal accomplishment by cultural, sportive, playful, scientific, erotic, artistic and political activities, rather than the desire for an infinite possession of products. Compulsive acquisitiveness is induced by the commodity fetishism inherent in the capitalist system, by the dominant ideology and by advertisement: nothing proves that its is part of an "eternal human nature", as the reactionary discourse wants us to believe. As Ernest Mandel emphasized: "The continual accumulation of more and more goods (with declining "marginal utility") is by no means a universal and even predominant feature of human behavior. The development of talents and inclinations for their own sake; the protection of health and life; care for children; the development of rich social relations $(. .$.$) all these become major motivations once basic material$ needs have been satisfied". ${ }^{7}$

This does not mean that there will not arise conflicts, particularly during the transitional process, between the requirements of the environment protection and the social needs, between the ecological imperatives and the necessity of developing basic infra-structures, particularly in the poor countries, between popular consumer habits and the scarcity of resources. A class-less society is not a society without contradictions and conflicts! These are inevitable: it will be the task of democratic planning, in an ecosocialist perspective, liberated from the imperatives of capital and profit-making, to solve them, by a pluralist and open discussion, leading to decision-making by society itself. Such a grass-roots and participative democracy is the only way, not to avoid errors, but to permit the self-correction, by the social collectivity, of its own mistakes.

Is this Utopia? In its etymological sense - "something that exists nowhere" - certainly. But arenot utopias, i.e. visions of an alternative future, wishimages of a different society, a necessary feature of any movement that wants to challenge the established order? As Daniel Singer explained in his literary and political testament, Whose Millenium?, in a powerful chapter entitled "Realistic Utopia", "if the establishment now looks so solid, despite the circumstances, and if the labor movement or the broader left are so crippled, so paralyzed, it is because of the failure to offer a radical alternative. (...) The basic principle of the game is that you question neither the fundamentals of the argument nor the foundations of society. Only a global alternative, breaking with these rules of resignation and surrender, can give the movement of emancipation genuine scope". 8

The socialist and ecological utopia is only an objective possibility, not the inevitable result of the contradictions of capitalism, or of the "iron laws

7 Ernest Mandel, Power and Money. A Marxist Theory of Bureaucracy, London, Verso, 1992, p. 206. 8 D. Singer, Whose Millenium? Theirs or Ours? New York, Monthly Review Press, 1999, pp. 259-260. 
of history". One cannot predict the future, except in conditional terms: in the absence of an ecosocialist transformation, of a radical change in the civilizational paradygm, the logic of capitalism will lead the planet to dramatic ecological disasters, threatening the health and the life of billions of human beings, and perhaps even the survival of our species.

To dream, and to struggle, for a new civilization does not mean that one does not fight for concrete and urgent reforms. Without any illusions on a "clean capitalism", one must try to win time, and to impose, on the powers that be, some elementary changes: the banning of the HCFCs that are destroying the ozone layer, a general moratorium on genetically modified organisms, a drastic reduction in the emission of the greenhouse gases, the development of public transportation, the taxation of polluting cars, the progressive replacement of trucks by trains, a severe regulation of the fishing industry, as well as of the use of pesticides and chemicals in the agro-industrial production. These, and similar issues, are at the heart of the agenda of the Global Justice movement, and the World Social Forums, which has permitted, since Seattle in 1999, the convergence of social and environmental movements in a common struggle against the system.

These urgent eco-social demands can lead to a process of radicalisation, on the condition that one does not accept to limit one's aims according to the requirements of "the [capitalist] market" or of "competitivity". According to the logic of what Marxists call "a transitional program", each small victory, each partial advance can immediately lead to a higher demand, to a more radical aim.

Such struggles around concrete issues are important, not only because partial victories are welcome in themselves, but also because they contribute to raise ecological and socialist consciousness, and because they promote activity and self-organisation from bellow: both are decisive and necessary pre-conditions for a radical, i.e. revolutionary, transformation of the world.

There is no reason for optimism: the entrenched ruling elites of the system are incredibly powerful, and the forces of radical opposition are still small. But they are the only hope that the catastrophic course of capitalist "growth" will be halted. Walter Benjamin defined revolutions as being not the locomotive of history, but the humanity reaching for the emergency breaks of the train, before it goes down the abyss. 